\title{
Ceftriaxone diffusion from blood to aqueous humour in man
}

\author{
D GOBEAUX, L AMBART, J L COUDERC, PH RENARD, \\ B DE CHARNACE, AND F LOKIEC
}

From the Departments of Anaesthesiology and Ophthalmology, Fondation Rothschild, Paris, and the Pharmacokinetics Laboratory, Centre René Huguenin, Saint-Cloud, France

SUMmARY Ceftriaxone penetrates into the aqueous humour in man. The interaction of indomethacin on the disposition of ceftriaxone appeared to be time-dependent. Indomethacin delayed ceftriaxone penetration into, but enhanced its persistence in, the aqueous humour, permitting a period of antibioprophylaxis covering the required time for surgical treatment.

Ceftriaxone (Rocephin), a third generation cephalosporin, is widely used in ophthalmological surgery to prevent postoperative infections. It is active against a wide variety of pathogens, and its long terminal half-life permits a single preoperative intravenous administration. Although highly protein-bound (more than $90 \%$ ), ceftriaxone shows good penetration of cerebrospinal fluid and eye.$^{12}$ It is well known that indomethacin, a prostaglandin synthesis inhibitor, interacts with several drugsepinephrine, ceftazidime, timolol. ${ }^{3-5}$ In this trial we studied the intraocular kinetics of ceftriaxone and the influence of indomethacin administration.

\section{Patients and methods}

Forty eight patients, 15 male and 33 female, ranging in age from 28 to 89 years (mean 72, SD 11), who had had cataract extractions were included in this study. They had no history of allergy to $\beta$-lactam antibiotics. All the operated eyes were free from infection and inflammation. The patients received $2 \mathrm{~g}$ of ceftriaxone during a 10-minute infusion. They were divided into two groups of 24 each. Group 1 received ceftriaxone alone, group 2 ceftriaxone and intrarectal indomethacin $(100 \mathrm{mg})$ the day before surgery. Local anaesthesia was with a lidocaine-etidocaine mixture, and sedation was by flunitrazepam and phenoperidin.

Biochemical tests on all the patients gave normal results and protein levels were within the normal range. Blood and aqueous humour $(0.1 \mathrm{ml}$ collected

Correspondence to D Gobeaux, Department of Anaesthesiology, Fondation Rothschild, 29 rue Manin, 75019 Paris, France. by anterior chamber paracentesis) samples were collected 30 minutes, and 1, 2, and 3 hours after the end of ceftriaxone infusion from six patients at each time for each group. Blood samples were centrifuged after collection, and plasma was removed and stored with aqueous humour $(\mathrm{AH})$ at $-20^{\circ} \mathrm{C}$ before assay. The samples were assayed by specific high liquid performance chromatography. ${ }^{6}$

Data were compared by Student's $t$ test and were expressed as mean and SE of mean.

\section{Results}

The concentrations of ceftriaxone in plasma and aqueous humour are shown in Tables 1 and 2 for the two groups of patients. The ceftriaxone plasma levels obtained in both groups of patients were in the same range as those reported. ${ }^{6}$

The penetration kinetics of ceftriaxone in aqueous humour were faster in group 1 than in group 2. Furthermore, we found a statistical difference between the two groups for plasma and aqueous humour ceftriaxone levels two hours after the end of

Table 1 Ceftriaxone plasma concentrations: ceftriaxone alone $(C A)$ and ceftriaxone plus indomethacin $(C I)$

\begin{tabular}{lll}
\hline Time (hour) & Plasma $\mu \mathrm{g} / \mathrm{ml} \mathrm{CA}$ & Plasma $\mu \mathrm{g} / \mathrm{ml}$ CI \\
\hline 0.5 & $215(36)$ & $193(38) \mathrm{NS}$ \\
1.0 & $205(41)$ & $176(15) \mathrm{NS}$ \\
$2 \cdot 0$ & $194(19)$ & $158(18) \mathrm{S}$ \\
$3 \cdot 0$ & $152(21)$ & $154(18) \mathrm{NS}$ \\
\hline
\end{tabular}

Each value is the mean (SE) for six patients. NS=not significant. $\mathrm{S}=$ significant $(\mathrm{p}<0.01)$. 
Table 2 Ceftriaxone aqueous humour concentrations: ceftriaxone alone (CA) and ceftriaxone plus indomethacin (CI)

\begin{tabular}{lll}
\hline Time (hour) & $\begin{array}{l}\text { Aqueous humour } \\
\mu g / m l ~ C A\end{array}$ & $\begin{array}{l}\text { Aqueous humour } \\
\mu g / m l C I\end{array}$ \\
\hline 0.5 & ND & ND \\
1.0 & $6 \cdot 0(3 \cdot 2)$ & ND \\
$2 \cdot 0$ & $1 \cdot 0(0 \cdot 7)$ & $3 \cdot 1(2 \cdot 2) \mathrm{S}$ \\
$3 \cdot 0$ & ND & $2 \cdot 1(4 \cdot 2) \mathrm{S}$ \\
\hline
\end{tabular}

Each value is the mean (SE) for six patients. $N D=$ below limit of detection. $\mathrm{NS}=$ not significant. $\mathrm{S}=$ significant $(\mathrm{p}<0 \cdot 01)$.

the antibiotic infusions: higher plasma concentrations and lower aqueous humour levels in group 1 and the contrary for group 2 . Three hours after infusion the statistical difference was only in the aqueous humour.

\section{Discussion}

The spectrum of ceftriaxone is similar to that of the other cephalosporins. The main difference is its long plasma half-life.' It is well known that ceftriaxone crosses the blood-brain and blood-ocular barriers, and prolonged aqueous humour levels are probably related to its prolonged plasma levels. ${ }^{2}$

Indomethacin seems to interfere with ceftriaxone. This interference involves ceftriaxone plasma and aqueous humour kinetics (levels and persistence).

The synergistic influence of both drugs is interest- ing because it permits a longer antibioprophylaxis for anterior chamber surgery. Furthermore indomethacin, either systemic or topical, may have a protective effect against cystoid macular oedema following cataract extraction. ${ }^{8}$

\section{References}

1 Seddon $\mathrm{M}$, Wise $\mathrm{R}$, Gillett AP, et al. Pharmacokinetics of Ro-13-9904, a broad-spectrum cephalosporin. Antimicrob Agents Chemother 1980; 18: 210-2.

2 Axelrod JL, Newton JC, Sarakhun C, et al. . A new cephalosporin with aqueous humor levels effective against Enterobacteriaceae. Arch Ophthamol 1985; 103: 71-2.

3 Camras CB, Feldman SG, Podos SM, Christensen RE, Gardner SK, Fazio DT. Inhibition of the epinephrine induced reduction of intraocular pressure by systemic indomethacin in humans. Am J Ophthalmol 1985; 100: 169-75.

4 Carbon C, Dromer F, Brion N, Cremieux AC, Contrepois A. Renal disposition of ceftazidime illustrated by interferences by probenecid, furosemide, and indomethacin in rabbits. Antimicrob Agents Chemother 1984; 26: 373-7.

5 Goldberg HS, Feldman F. Cohen MM, Clark L. Effect of topical indomethacin and timolol mateate on intraocular pressure in normal subjects. Am J Ophthalmol 1985; 99: 576-8.

6 Trautmann KH, Haeffelfinger I. Determination of the cephalosporin RO 13-9904 in plasma, urine and bile by means of ion-pair reversed phase chromatography. J High Resolution Chromatogr Commun 1981; 4: 54-9.

7 Pollock AA, Tee PE, Patel IH, Spicehandler J, Simberkoff MS, Rahal JJ Jr. Pharmacokinetic characteristics of intravenous ceftriaxone in normal adults. Antimicrob Agents Chemother 1982; 22: 816-23.

8 Yannuzi L. A perspective on the treatment of cystoid macular edema. Surv Ophthalmol 1984; 28 : 540.

Accepted for publication 6 October 1988. 